\title{
Presseetisk kontrol
}

\section{AF ANNEGRETE SKOVBJERG OG OLUF JØRGENSEN}

Artiklen beskriver det presseetiske systems udvikling og giver eksempler på nævnets praksis. Det danske system er unikt, fordi det er lovreguleret og Pressenævnet er organiseret som et offentligt organ. Denne ordning er ikke et problem, men der peges i stedet på, at nævnets manglende synlighed er en svaghed. I forlængelse heraf kommer anbefalinger til, hvilke tiltag der vil kunne styrke Pressenævnets betydning. Artiklen beskriver også mediers egne etiske ordninger, og i den afsluttende vurdering af formål og funktioner bliver sådanne ordninger sammenlignet med Pressenævnet.

Presseetik handler om mange spørgsmål bl.a.: Hvor sikker skal journalisten være, før han publicerer en beskyldning mod en borgmester om korruption? Skal borgmesteren først konfronteres med oplysningerne og have mulighed for at komme til orde? Hvor går grænsen for brug af skjulte mikrofoner og kameraer? Er der noget i vejen for, at en forretning får en pæn redaktionel omtale, når den har betalt et større beløb for en annonce? Kan fejl på et website rettes diskret, eller skal rettelsen markeres? Skal journalister altid have samtykke fra forældre, før de må interviewe børn og unge?

Presseetik kan handle om samme spørgsmål som strafferegler f.eks. krænkelser af private forhold, men den presseetiske vurdering behøver ikke at være identisk med domstolens i en straffesag. Presseetik kan også handle om andre emner, f.eks. rettelse af fejl, genmæle til en krænket person eller navne i retsreportage.

Nationale, presseetiske retningslinjer er typisk vedtaget af branchens organisationer. Ifølge en UNESCO-rapport fra 2000 
var der presseetiske regler i 63 ud af 78 lande, og 43 af disse lande havde et særligt presseetisk kontrolorgan (Raaum, 2003: 174). Etiske retningslinjer kendes også inden for faggrupper f.eks. International Federation of Journalists (IFJ). Desuden har nogle medier opstillet sine egne etiske retningslinjer heraf enkelte med særlige interne kontrolordninger f.eks. ,læsernes redaktør“.

\section{Lovregulering af det danske system}

Med mediansvarsloven fik Danmark i 1992 et lovfæstet Pressenævn, der er organiseret som et offentligt organ. Denne ordning er usædvanlig. I andre lande er presseetiske kontrolorganer typisk private organisationer i pressens eget regi, og sådan var det også i Danmark før 1992. Presseloven fra 1938 havde dog regler om redaktørens pligt til at optage en berigtigelse af faktiske oplysninger med klageadgang til Berigtigelsesnævnet ved afslag (Frøbert, 2000: 235-240).

Det første presseetiske kontrolorgan i verden blev etableret i Sverige i 1916, der fulgte op med et presseetisk regelsæt i 1923. Norge fik et klageorgan i 1929 og et regelsæt i 1936. I England fungerede Press Council fra 1951 uden et formuleret regelsæt, men det kom i 1991 og samme år blev etableret et nyt kontrolorgan: Press Complaints Commission. USA har ikke et nationalt klageorgan for presseetik. I en kort periode fra 1973 til 1984 eksisterede en ordning (NCC), men der var ikke tilstrækkelig interessere for at opretholde den, og de fleste delstatsordninger er også nedlagt igen. Til gengæld har mange medier i USA oprettet egne ordninger (Raaum, 2003: 25-45).

I Danmark blev retningslinjer for god presseskik vedtaget i 1960 af DDF (Danske Dagblades Fællesrepræsentation senere Danske Dagblades Forening). Det første regelsæt handlede primært om retsreportage. I 1964 fulgte DDF op med etablering af Dansk Pressenævn. Journalistforbundet kunne ikke tilslutte sig ordningen, fordi forbundet ikke kunne få paritet med redaktørerne ved udpegning af medlemmer til nævnet.

I 1981 blev retningslinjerne revideret og fik stort set den nuværende udformning. Journalistforbundet kunne hverken få indført en ,samvittighedsklausul“, der gav journalister ret til at sige nej til 
en opgave, eller en regel om at hindring af berettiget offentliggørelse (,noninformation“) er i strid med god presseskik. Forbundet valgte derfor igen at stå uden for. Før 1992 omfattede Pressenævnet kun dagblade og kun de, der tilsluttede sig. Jyllands-Posten, Politiken, Ekstra Bladet og Information valgte at stå uden for.

Medieansvarsudvalget, der forberedte medieansvarsloven, nåede til enighed om det presseetiske system: Vejledende presseetiske regler, Pressenævnets sammensætning og organisering som offentligt organ, og at alle massemedier skulle omfattes (Medieansvarsudvalget, 1990). Den nuværende ordning blev etableret 1. januar 1992, da medieansvarsloven afløste den tidligere presselov.

Medlemmer i Pressenævnet bliver udnævnt af justitsministeren for en 4-årig periode (medieansvarsloven $\$ 41$ ). Højesterets præsident indstiller formand og næstformand og redaktionelle ledelser, Journalistforbundet og Dansk Folkeoplysnings Samråd indstiller hver to medlemmer. Hvert medlem har en stedfortræder. Pressenævnet er uafhængigt i sit arbejde. Der kan ikke klages over Pressenævnets afgørelser til andre myndigheder eller Folketingets Ombudsmand. Uafhængigheden betyder også, at hverken minister eller andre kan give instrukser til Pressenævnet.

Lovregulering har traditionelt spillet en rolle for radio og tv, og for disse medier har der i en række lande været et offentligt organ for presseetisk kontrol. I Danmark fungerede Radionævnet som klageorgan, indtil radio og tv kom under Pressenævnet i 1992. I Sverige og Storbritannien findes fortsat særlige offentlige klageorganer for radio og tv, der bl.a. behandler sager om presseetik.

Medieansvarsloven $₫ 34$ bestemmer, at massemediernes indhold og handlemåde skal være i overensstemmelse med god presseskik, men loven fastsætter ikke hvilke krav, der følger heraf. Medieansvarsudvalgets begrundelse lød: De presseetiske regler skal kun være vejledende, de skal afspejle opfattelser, der har udbredt accept i branchen, og give mulighed for at Pressenævnet tager stilling til nye situationer (Medieansvarsudvalget, 1990: 327). God presseskik skal således give god plads til både konkrete skøn og udvikling af nye standarder. 


\section{Pressenævnet i praksis}

I de første år efter nedsættelsen af Pressenævnet var der en jævn stigning $i$ antallet af afgjorte sager. Men siden midten af halvfemserne har antallet ikke udviklet sig markant - godt 100 afgjorte sager om året med undtagelse af et par enkelte udsving. Hvis man kigger hen over hele perioden, er der ikke tegn på hverken stigende eller faldende tendens $i$ antallet af klagebehandlinger. (Tallene for 2003 er ikke sammenlignelige på grund af overgang til anden opgørelsesmetode).

\section{Figur 1.}

Antal afgjorte sager

Antal afgjorte sager

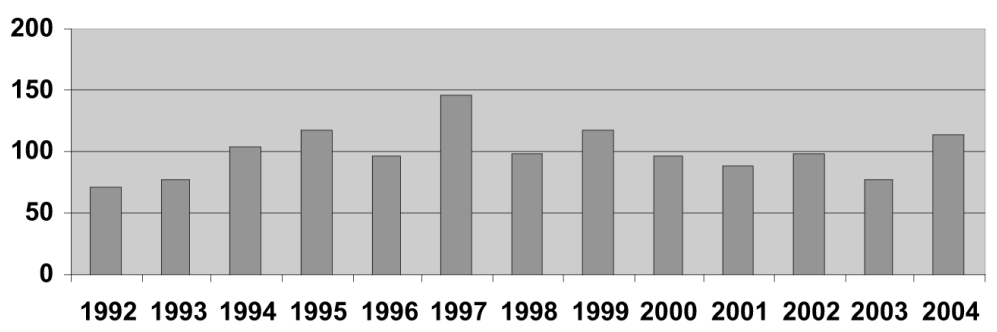

Pressenævnet behandler to typer klagesager: Dels klager over overtrædelse af god presseskik og dels klager over medier, der har afvist at bringe et genmæle fra en person, der mener at være berettiget.

Nogle klager når ikke frem til en egentlig behandling hos Pressenævnet, men bliver afvist af nævnets formand. Det drejer sig hovedsageligt om afvisninger pga. manglende klageadgang, overskridelse af tidsfrist eller pga. nævnets manglende kompetence.

Som det fremgår af figur 2 er det langt fra alle, der får medhold i deres klager over medierne. Hvis man kigger samlet på pressenævnskendelserne siden 1992 viser statistikken, at ca. 30\% af de afgjorte sager ender med, at klagerne får helt eller delvist ret. Ca. $75 \%$ af disse afgørelser medfører et pålæg til medierne om at offentliggøre kendelsen.

I nævnets årsberetninger tages nogle generelle problemstillinger op på baggrund af klagesager, der er behandlet i løbet af 


\section{Figur 2.}

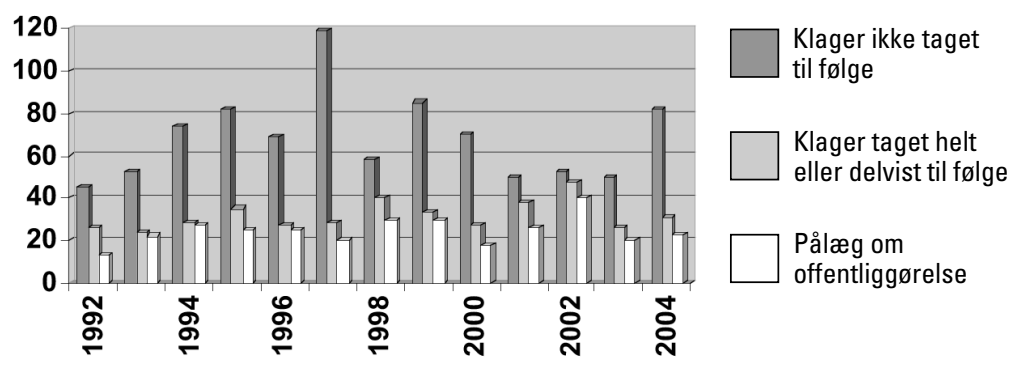

det pågældende år. Her kan enkeltsager om samme emne fungere som afsæt for mere konkluderende og principielle udtalelser fra Pressenævnet. I det følgende beskrives to eksempler på denne praksis.

\section{Skjulte optagelser - skjult identitet}

I de senere år har journalister i stigende grad gjort brug af skjulte kameraer og mikrofon ved de elektroniske medier. Det er især ved tv-indslag, at tendensen til at bruge skjulte optagelser er stigende, hvilket i høj grad skyldes, at teknologien har gjort det muligt at lave optagelser af acceptabel kvalitet med kameraer, der er meget lette at skjule. Hvis man ser på kendelser i Pressenævnet, der omhandler brug af skjulte optagelser, er der ganske vist ikke en tilsvarende stigning at spore, men siden 1997 har nævnet hvert år afsagt kendelser om skjulte optagelser - i gennemsnit ca. tre om året.

Flere af klagerne har været rettet mod DRs tidligere dokumentarserie „Rapporten“. Den første gav Pressenævnet anledning til at udforme principielle retningslinjer, som fremgik af årsberetningen for 1997. Rapporten afdækkede forretningsmetoder hos inkassobureauer, og der indgik skjulte optagelser, hvor en journalist interviewede konsulenter fra forskellige inkassobureauer.

Pressenævnet konkluderede, at offentliggørelse af skjulte optagelser som hovedregel vil være i strid med god presseskik, med mindre der enten foreligger et direkte eller indirekte samtykke fra den medvirkende eller: 
- offentliggørelsen tjener en samfundsmæssig interesse, der klart overstiger hensynet til de personer der optræder, og

- den journalistiske dokumentation ikke eller kun meget vanskeligt kan skaffes på anden måde (Pressenævnet, 1997: 12).

Pressenævnet pointerede endvidere, at de optagne personer bør anonymiseres ved udsendelsen, særligt når de ikke er hovedansvarlige for de forhold, der afsløres.

De følgende år behandlede nævnet forskellige aspekter ved brugen af skjulte optagelser. Et par af kendelserne drejede sig om sager, hvor en medarbejder fra medierne spillede en rolle som hæler og opfordrede folk til at bryde loven ved at købe hælervarer. Her udtalte nævnet sig igen principielt og understregede vigtigheden af „en nøje afvejning i hvert enkelt tilfælde af den samfundsmæssige interesse i forhold til den enkeltes krav på beskyttelse“ ... samt en nøje overvejelse om de personer, der figurerer på optagelserne, har krav på at blive anonymiseret (Pressenævnet, 1998: 8).

I årsberetningen for 2004 behandlede Pressenævnet principielle spørgsmål om offentliggørelse af telefonsamtaler. Her præciserede nævnet at man udover den samfundsmæssige interesse lægger vægt på, om optagelserne er lavet med personer, der er vant til kontakt med pressen og derfor må forventes at kende til de journalistiske arbejdsmetoder (Pressenævnet, 2004: 22).

\section{Interview og fotografering af børn og unge}

Pressenævnet har behandlet en række sager, hvor journalister har interviewet mindreårige uden forældrenes samtykke. Klagerne er kommet fra forældre, der ikke har givet samtykke til offentliggørelse af interviews med deres børn.

I årsberetningen fra 2004 fremlagde nævnet principielle synspunkter efter et par konkrete sager fra det foregående år. Pressenævnet udtaler her, at der ved interviews med mindreårige er to overordnede hensyn at tage i betragtning: På den ene side hensynet til den mindreårige, der måske ikke kan overskue konsekvenserne af sine udtalelser og på den anden side hensynet til den mindreåriges ytringsfrihed. Det sidste kan især komme på 
tale, hvis der er en interessekonflikt mellem den mindreårige og forældre. Nævnet udtaler, at ,jo yngre den mindreårige er, og jo mere private oplysningerne er, desto sværere vil det være for nævnet at frikende mediet" (Pressenævnet, 2004: 21).

Pressenævnet fremlægger nogle overvejelser, som medierne bør gøre, inden de offentliggør interviews med børn og unge. Nævnet påpeger, at forældreretten ikke udelukker, at mindreårige selv kan tage stilling til, om de vil deltage i interviews. Det afgørende er de konkrete omstændigheder, og hvor private udtalelserne er. For eksempel udtalte nævnet kritik i en af sagerne, hvor en 17-årig pige havde udtalt sig om sit tidligere stofmisbrug, prostitution og kriminalitet. Her var det ifølge et flertal i Pressenævnet ikke nok, at pigen var næsten myndig, fordi udtalelserne havde en meget privat karakter.

\section{Høring, berigtigelse og genmæle}

I databasen www.cfje.dk/mediejura er Pressenævnets sager kategoriseret på en række emner efter aftale med nævnet. Her topper sager om høring sammen med genmæle, mens der er få sager om berigtigelse. Hvordan hænger det sammen?

Det presseetiske krav om høring betyder, at en oplysning om faktiske forhold, der kan skade eller krænke, skal præsenteres for den, der rammes. Høring giver dels mulighed for at få rettet faktuelle fejl dels at få en kommentar fra den person eller organisation, oplysningen handler om. Det presseetiske krav om høring gælder før publicering, og det er ofte nemt for Pressenævnet at konstatere, om kravet er opfyldt. Hvis det haster at få en nyhed frem, skal mediet dog ikke vente, hvis det har gjort rimelige anstrengelser for at få kontakt. Den pågældende skal ikke kunne hindre offentliggørelse ved at gemme sig eller nægte at udtale sig.

Berigtigelse betyder, at et medie, der har publiceret en forkert oplysning om faktiske forhold, efterfølgende retter fejlen. Det skal ske hurtigst muligt ifølge de presseetiske retningslinjer. Berigtigelse er synonymt med „dementi“ eller „rettelse“. Berigtigelse skal foretages af mediet, så snart det har fået kendskab til en fejl. Pligten til at berigtige gælder uanset der klages eller ej, om 
den medfører skade eller ej, om fejlen er stor eller lille medmindre den er uden betydning.

Genmæle betyder at komme til orde med en replik. Med presseloven fra 1938 fik Danmark lovregler om genmæle, men desværre blev genmæle i presseloven kaldt berigtigelse, og det giver stadig forvirring, fordi mange hænger fast i den ældre terminologi. Med medieansvarsloven blev betegnelsen genmæle indført. Retten til genmæle gælder - ligesom berigtigelse - kun ved oplysninger om faktiske forhold. Men der er vigtige forskelle. Pligten til at publicere et genmæle forudsætter ikke, at fejl er erkendt eller kan bevises, men at der er grund til tvivl om oplysningens korrekthed, og at den kan påføre skade af en vis betydning (medieansvarsloven $\S 36$ ). Pligten til genmæle gælder ved anmodning fra den person eller organisation, oplysningen vedrører, når anmodningen er modtaget senest 4 uger efter publicering. Et medie kan kræve, at klageren selv udformer genmælet, og har kun pligt til at bringe det, når det begrænses til de nødvendige faktiske oplysninger (Jørgensen, 2004: 180-186).

Pressenævnet har ikke mulighed for bevisførelse og kan derfor ikke tage stilling til krav om berigtigelse, når påstand står mod påstand, og det ikke umiddelbart kan fastslås, hvad der er op og ned. I klare tilfælde sørger enhver fornuftig redaktør for berigtigelse, når han bliver klar over fejlen. Hvis redaktøren afslår på grund af tvivl, får klageren typisk ikke noget ud af at gå til Pressenævnet. Hvis sagen er tilstrækkeligt dokumenteret, kan Pressenævnet dog kritisere et medie, der ikke har berigtiget på eget initiativ. Nævnet kan derimod ikke give pålæg om berigtigelse, men kun om genmæle.

\section{Begrænset klageadgang}

Ekstra Bladet bragte 14. august 2004 over to sider stærkt negativ omtale af landsbyen Hampen - „håbløshedens endestation“ hvor børn og unge var præget af kriminalitet, dårlige tænder, dårlige skolekundskaber og indavl. Pressenævnet afviste at behandle en klage over artiklerne (Pressenævnet, 2004: 32). Nævnet lagde vægt på, at artiklerne gav en generel beskrivelse af bysamfundet og dets beboere, og at forældreparret, der klagede, derfor ikke 
havde en "retlig interesse" i klagen. Det var ikke nok, at de boede i lokalområdet, at deres barn deltog i aktiviteter i Hampen, og at manden var leder af daginstitutionen i byen.

Ifølge medieansvarsloven $\S 43$ stk. 2 kan Pressenævnet afvise en klage, hvis klageren ikke har en „retlig interesse“. Begrundelsen er, at personer og organisationer, der er krænkede, selv er de nærmeste til at vurdere, om der er sket en krænkelse. Og det kan virke anmassende, hvis et kontrolorgan vil se nærmere på en krænkelse, som de pågældende ikke selv tager særligt alvorligt eller ønsker at glemme hurtigst muligt. De samme hensyn ligger bag straffelovens påtaleregler i sager om krænkelser af private forhold og injurier.

Kun enkeltpersoner, virksomheder og myndigheder, der er direkte omtalt, afbilledet eller på anden måde identificeret i mediet, kan klage (Ingerslev, 1998: 250). Det betyder, at der typisk ikke er mulighed for at klage til Pressenævnet over fejlinformation om et lokalsamfund eller en befolkningsgruppe, der fx stemples som kriminelle eller degenereret indavl.

Pressenævnet kan ifølge medieansvarsloven $§ 44$, stk. 2 tage en sag op på eget initiativ, hvis den er væsentlig eller principiel, og nævnet indhenter en udtalelse fra den krænkede. Men denne mulighed er kun benyttet i et enkelt tilfælde, der handlede om billeder, der var optaget af kronprinsen under private former (Pressenævnet, 1997: 5).

I Norge kan generalsekretæren i Norsk Presseforbund rejse sager, der har stor principiel interesse, eller hvor der er rimelig grund til at bistå den krænkede. Han skal dog indhente samtykke fra enkeltpersoner, før sagen rejses ved Pressens Faglige Utvalg (Raaum, 2003: 153). I Sverige har den særlige presseombudsmand mulighed for at rejse sager ved klageorganet „Pressens Opinionsnämd“ med samtykke.

\section{Presseetiske problemer, hvor nævnet ikke spiller nogen rolle}

Sammenblanding af reklamer og redaktionel tekst er omfattet af de presseetiske regler, men selv om overtrædelser hos visse ugeaviser næsten er sat i system, bliver de ikke til sager i Pressenæv- 
net, fordi klageadgangen er begrænset til direkte krænkede. Læserne kan ikke klage, selv om de bliver vildledt som forbrugere. En klage kunne komme fra en konkurrent til et firma, der får redaktionel omtale som supplement til annoncen, men det sker ikke, måske fordi konkurrenten regner med selv at få brug for positiv omtale.

Radio- og tv-nævnet, der er kontrolorgan for de særlige reklameregler for radio og tv, ser også på sager om skjult reklame. I Pressenævnets fravær er det ved den trykte presse alene Forbrugerombudsmanden, der behandler sager om skjult reklame. Det gør han efter markedsføringsloven (Forbrugerombudsmanden, 2005).

Pressenævnet tager kun undtagelsesvis stilling til spørgsmål om kildekreditering, citater og plagiater. Pressenævnets tilbageholdenhed hænger både sammen med, at det ikke kan foretage bevisførelse, og at det ikke kan afgøre ophavsretlige spørgsmål.

Internetmedier med redigeret nyhedsformidling kan blive omfattet af medieansvarsloven ved anmeldelse til Pressenævnet. En række internetmedier har valgt at blive omfattet medieansvarsloven og dermed af Pressenævnets kompetence. Pressenævnets sager om internetmedier handler typisk om traditionelle spørgsmål. Tilsyneladende er der ikke rejst spørgsmål ved Pressenævnet om nye etiske problemstillinger, der opstår på grund af internetmediets særlige karakter. Eksempelvis giver den flygtige karakter grund til at overveje særlige krav om synlighed ved berigtigelse.

\section{Fordele og ulemper}

Trods opbygningen som offentligt organ fungerer det danske system stort set som systemerne i andre nærtstående lande, der har private selvjustitssystemer. Pressenævnet tager udgangspunkt i de vejledende retningslinjer, der tidligere var skabt $\mathrm{i}$ branchen, og halvdelen af nævnets medlemmer er udnævnt efter indstilling fra pressens organisationer. Pressenævnet fungerer reelt som et uafhængigt organ. Principperne om ytringsfrihed i Den Europæiske Menneskeretskonvention skal overholdes, hvad enten klageorganet er organiseret som branchens private etiske udvalg eller som et offentligt organ (Pressenævnet, 2001: 1 og 2004: 4). 
Private selvjustitssystemer vil typisk kræve et større engagement fra de faglige organisationer. Det kan på den ene side være en fordel, hvis det giver større debat om kontrolorganets praksis. Et offentligt system kan på den anden side give organisationerne den fordel, at de ikke behøver at bruge kræfter på interne uenigheder om presseetik og i stedet kan bruge kræfterne på at være interesseorganisationer for ytringsfrihed og pressefrihed.

Det er en fordel ved den danske model, at den giver større sikkerhed for medlemmernes uafhængighed i forhold til de organisationer, der har indstillet dem. Og modellen betyder, at forvaltningsloven og offentlighedsloven gælder. Den største principielle svaghed er, at justitsministeren udnævner Pressenævnets medlemmer. Ministeren skal bygge på indstillinger, men det kan ikke udelukkes, at ministerens kompetence kan bruges til at påvirke nævnet, og den giver i hvert fald ikke omverdenen et overbevisende indtryk af pressefrihed i Danmark. Den formelle udnævnelse burde enten foretages af de organisationer, der nu nøjes med at indstille, eller ske i et organ, der står uden for det politiskadministrative system for eksempel Folketingets Ombudsmand.

De danske regler for god presseskik er ikke ændret siden 1990, hvor medieansvarsudvalget tilføjede bløde principper om en „samvittighedsklausul“ og „,noninformation“ i indledningen. Ellers stammer ordlyden fra 1977 eller tidligere (Betænkning om presseetik, 1977). De vejledende presseetiske retningslinjer blev gengivet i et bilag til bemærkningerne til forslaget til medieansvarslov (Folketingstidende 1990-91, 2.samling, tillæg A, sp 3047 ff). Det har givet tvivl, om de kan ændres uden Folketingets medvirken, men eftersom Medieansvarsudvalget lagde vægt på, at Pressenævnet kan udvikle principperne, må det også være muligt for Pressenævnet at tage initiativ til ajourføring af teksten og vedtage nye vejledende retningslinjer for sit arbejde. Da medieansvarsudvalget lagde vægt på, at de presseetiske regler afspejler udbredte holdninger i pressen, må pressens organisationer nødvendigvis spille en central rolle ved en eventuel ajourføring.

I andre lande bliver de presseetiske regler ændret jævnligt, fx i Norge og Sverige. I Storbritannien har en komité af 15 redaktører til opgave at ajourføre de presseetiske regler, og den har foretaget talrige ændringer (Raaum, 2003: 84). 
På et eller andet tidspunkt må de presseetiske regler også ajourføres i Danmark. Ganske vist er de ikke håbløst forældede, og Pressenævnet har mulighed for at tage stilling til nye problemstillinger. Men for borgere, der overvejer at klage, ville det være nyttigt, hvis reglerne gav god vejledning om, hvad Pressenævnet tager sig af.

Nævnets eneste sanktionsmulighed er at stille krav til mediet om publicering af nævnets kritik - i praksis et resumé. Pressenævnet afgør hvor meget af kritikken, der skal publiceres, men som hovedregel ikke hvor i mediet, kritikken skal placeres. Nævnet har dog henstillet, at dets kritik af tv-nyheder bliver oplæst i forbindelse med stationens hovednyhedsudsendelse. Hvis Pressenævnet skal have styrket betydningen som klageorgan, må nævnets kritik være ligeså synlig i de trykte medier. Nævnet har fx mulighed for at kræve, at nævnets kritik skal bringes på forsiden, når en væsentlig fejl har været publiceret der. Det kunne gøres uden at udarte til et rigidt krav om samme spalteplads.

Det bør også overvejes, om klageadgangen altid skal betinges af „retlig interesse“, eller om nævnet skulle tage nogle sager op af egen drift. Den primære begrundelse for den snævre klageadgang er, at den krænkede er nærmest til at vurdere om der er grund til klage. Men denne begrundelse kan ikke udelukke, at Pressenævnet tager sager op af egen drift, når den krænkede person ikke har mulighed for at gøre det, fx fordi han befinder sig et fjernt land. Pressenævnet kan ved en ændring af forretningsordenen sikre, at medlemmer, der medvirker ved en afgørelse om optagelse af en sag, ikke kan medvirke ved sagens behandling og afgørelse (forretningsordenen $\S 7$, stk.3).

\section{Mediers egne etiske retningslinjer}

I Danmark har der ikke som i USA været tradition for, at medierne udfærdiger egne etiske retningslinjer. Mens mange amerikanske medier arbejder med interne regler, holder de fleste danske medier sig til de rammer som medieansvarsloven og de vejledende regler for god presseskik udstikker. Da Helle Nissen Kruuse i 1991 lavede en undersøgelse blandt 12 aviser og to elektroniske medier, fandt hun kun to steder med nedskrevne regler (Kruuse, 
1991: 20). Selv om mange andre danske virksomheder i årevis har lagt stadig større vægt på at arbejde med synlige etiske værdisæt, har det indtil for få år siden ikke været et varmt emne på medierne. Noget tyder dog på, at der alligevel er en udvikling i gang hos danske medievirksomheder.

Center for Journalistik og Efteruddannelse (CFJE) lavede i 2005 en rundspørge om etiske retningslinjer til ca. 50 danske medier. Selv om undersøgelsen ikke er helt repræsentativ, giver den dog et fingerpeg om, hvordan en række medier håndterer etiske problemstillinger. Otte ud af 50 havde etiske retningslinjer, der er tilgængelige på nettet. Tre medier bekendtgjorde, at de var på vej med regler mens enkelte fortalte, at de har etiske retningslinjer, der ikke er tilgængelige for offentligheden.

Databasen www.cfje.dk/mediejura rummer en oversigt over medier med og uden etiske retningslinjer, samt et link til de retningslinjer, som er tilgængelige på nettet. Når man kigger nærmere på, hvordan medierne formulerer de etiske retningslinjer, viser der sig at være ret store forskelle. Et kig på de tre største morgenaviser Jyllands-Posten, Politiken og Berlingske Tidende afslører markante forskelle i både omfang og indhold.

Berlingske Tidendes etiske værdisæt opstiller i kort form en række værdiudsagn, som avisen arbejder ud fra: Alsidighed, troværdighed, fri meningsdannelse og et borgerligt grundsyn. Sådan skal læserne opleve avisen. Redaktionen skal skrive det væsentlige, være grundige, høre begge parter og rette med et smil. Her er tale om meget overordnende udsagn, der informerer læserne om nogle helt grundlæggende værdisyn, men ikke peger ind på journalistikken og dens arbejdsmetoder.

Jyllands-Posten har ligesom Berlingske Tidende en række overordnede udsagn, der beskriver avisens værdigrundlag med en liberal borgerlig linje uden tilknytning til et politisk parti. Væsentlighedsprincippet, troværdighed og vedkendelse af fejl optræder ligeledes her som vigtige forudsætninger for avisens redaktionelle linje. Jyllands-Posten har taget et skridt videre ind i beskrivelsen af et journalistisk regelsæt, de redaktionelle grundpiller. Her beskrives, hvordan der holdes skarp adskillelse mellem avi- 
sens egne holdninger i de ledende artikler og avisens journalistiske indhold. Kun indenfor særlige genrer må journalister udtrykke personlige holdninger, ligesom deres tilhørsforhold til politiske partier og interesseorganisationer skal overvejes i forhold til deres stofområder. Reglerne berører desuden forholdet til kilder, brug af anonyme kilder og billedmanipulation.

Politiken går noget længere i beskrivelsen af etikken for det journalistiske arbejde. Ud over det generelle værdisæt, fremlægges mere detaljerede retningslinjer for journalistikken, hvor det eksempelvis vægtes, at „rubrikker, underrubrikker, henvisningstekster og spisesedler skal have dækning i artiklen“. Og når det gælder parts-interview skal „begge/alle parter i en sag komme til orde. Den kritiserede parts synspunkter må ikke gemmes til sidst, men skal fremgå fra starten af artiklen og/eller i underrubrikken“. Reglerne rummer også retningslinjer for reportage-genren, billeder og forholdet til kilderne.

Politiken har ud over de mere udførlige etiske retningslinjer ansat en Læsernes Redaktør for at sikre, at faktuelle fejl rettes øjeblikkeligt og synligt, „... Læsernes redaktør, der uafhængigt af redaktionsledelsen behandler klager og henvendelser fra læserne om fejl, herunder brud på de etiske regler journalistik skal være fair og korrekt“. Nogle kritikere af detaljerede etiske retningslinjer mener, at de rummer faren for, at den enkelte stopper med at tænke selv for i stedet at fokusere på reglerne. Politiken indleder dog med at etisk regel nummer et er at bruge sin sunde fornuft. Her ligger en markering af, at etiske regler selvsagt ikke træder i stedet for journalistens sunde fornuft - eller hvad man kunne oversætte til den mere personlige etik.

Blandt de øvrige mediehuse med etiske retningslinjer er Vejle Amts Folkeblad, Ugebrevet Mandag Morgen, Fyens Stiftstidende og Danmarks Radio, som både har programetik og leverandøretik. Danmarks Radio har ansat en lytter- og seerredaktør, der har særlige opgaver med håndtering af etiske problemstillinger.

Eksemplerne viser tre forskellige måder at forholde sig til etik og værdier på. I den ene ende af skalaen har vi Berlingske Tidende, der åbner et vindue op og lader læserne kigge ind på det 
værdigrundlag avisen og den redaktionelle linje bygger på. Læserne må siden selv vurdere om journalistikken lever op til sine idealer. I den anden ende befinder Politiken sig med et sæt mere udførlige etiske regler, hvor man lader læserne få et vist indblik i den redaktionelle proces og de journalistiske metoder. Man lader læserne kigge journalisterne lidt mere over skulderen, og signalerer tydeligt ved at installere en Læsernes Redaktør, at man ønsker at være i dialog om avisens etik. Det giver større gennemsigtighed i selve arbejdsprocessen og ikke kun i de værdier, der ligger bag.

Intet tyder på at hverken grundige etiske retningslinjer eller en læsernes redaktør får Politiken eller andre medier til at fremstå som ufejlbarlige nyhedsleverandører med lutter fromme hensigter. I marts 2006 har læsernes redaktør på Politiken påpeget, at der i dækningen af Muhammed-krisen har været for mange fejl i avisen. Blandt årsagerne til fejlene nævner han tidspres og manglende koordinering, før aviserne bliver trykt (Politiken, 11-32006). Her berører læsernes redaktør en af de centrale problemstillinger i forhold til etikken på mediearbejdspladserne. Der er nok ingen tvivl om, at et stigende nyhedspres og større konkurrence på mediemarkedet øger antallet af hurtige redaktionelle beslutninger, som igen lægger pres på etikken - både hos den enkelte journalist og i det redaktionelle miljø. Det stiller krav til medierne om at finde en måde at håndtere både nyhedspres og etiske krav på redaktionerne.

\section{Formål og funktioner}

Ifølge medieansvarsudvalget har det presseetiske system tre formål (Medieansvarsudvalget, 1990: 325):

1. Det tilbyder en formløs, hurtig, diskret og gratis klageform sammenlignet med en retssag. Hvis krænkelsen vedrører privatlivet kan en retssag tilmed betyde yderligere belastning ved fornyet interesse fra medierne. Det presseetiske system kan skaffe borgeren en vis oprejsning, uden den belastning som en retssag kan medføre.

2. Det presseetiske system har en bufferfunktion, fordi det formindsker behovet for at anvende de almindelige retsregler i forhold til pressen. 
3. Endelig har Pressenævnet gennem sine afgørelser mulighed for at påvirke det almindelige presseetiske niveau.

Bedømt ud fra klagesagernes antal har Pressenævnet en vis betydning som klageorgan, men ikke særlig stor. Ressourcestærke personer og organisationer vil ofte foretrække en retssag, der giver mulighed for bevisførelse og kontant gevinst. Den nemme klageadgang til Pressenævnet kan have større betydning for personer, der ikke har ressourcer eller lyst til at føre retssag. Problemet er, at mange borgere formentlig ikke kender Pressenævnet.

Interne klagesystemer kan ikke erstatte Pressenævnets klagebehandling. Dels er det tvivlsomt, om interne ordninger kan give borgeren samme sikkerhed for uvildig behandling, dels bestemmer det enkelte medie selv, om det vil have en intern ordning, og hvordan det skal fungere. Spredte interne systemer kan heller ikke give pressen noget værn mod retssager eller mod lovgivning.

Pressenævnet var tiltænkt en bufferfunktion i forhold til retssager mod pressen. Det er tænkeligt, at nogle har afstået fra retssager, men omvendt kan andre være fristet til at anlægge retssag efter at have fået medhold i Pressenævnet, fordi flere domme lægger vægt på Pressenævnets afgørelse ved vurdering af krav om $ø$ konomisk godtgørelse. Pressenævnet har formentlig haft en vis betydning som buffer mod lovgivning. men denne betydning er mindsket i takt med, at Den Europæiske Menneskeretsdomstol gennem sin praksis har skabt et værn mod indgreb i ytringsfriheden. Uden Pressenævnets praksis vedrørende skjult kamera er det dog sandsynligt, at der var kommet lovgivning.

Pressenævnet har en vis betydning for det almindelige presseetiske niveau. Det gælder for eksempel nævnets praksis om høring, genmæle og brug af skjult kamera og mikrofon.

Mediernes egne etiske retningslinjer kan være mere effektive redskaber til at holde fokus på etikken. De kan bruges som løftestang for etiske diskussioner og en øget etisk bevidsthed i forskellige dele af den redaktionelle proces. Men selv om etikken er nedfældet, har man ingen garanti for at diskussionerne kommer til at leve. Her er det redaktionelle miljø helt afgørende for, hvorvidt etikken i sidste ende kommer på dagsordenen.

Journalisters og mediers evne til selvkritik har afgørende be- 
tydning for presseetikken. Det samme gælder den gensidige mediekritik. Krav til åbenhed må også gælde journalistik og medier, og loyalitet over for fagfæller er farlig, hvis den betyder, at der bliver dækket over væsentlige fejl.

Korrektion af fejl og vildledninger kan i mange tilfælde ske effektivt gennem mediernes selvkritik og gensidig kritik. Fejl, der har nyhedsværdi, har gode chancer for at blive rettet i andre medier, hvis mediet ikke gør det selv. Men der er tilfælde, hvor ingen har interesse i korrektion undtagen den enkelte borger, der er ramt. Der er også tilfælde, hvor en borger, der er krænket, hverken har råd eller lyst til at føre retssag. Det er især i sådanne tilfælde, at der er brug for, at Pressenævnet bliver mere synligt og i særlige tilfælde tager en sag op på eget initiativ, når den krænkede person er ude af stand til selv at gøre det.

\section{Opsummering}

Presseetisk kontrol er ikke et særligt dansk fænomen. Faktisk kom Danmark senere i gang end andre lande, vi normalt sammenligner os med. I de fleste lande er presseetiske kontrolorganer etableret af branchen og fungerer som private selvjustitsorganer. Med medieansvarsloven fra 1992 fik Danmark et lovreguleret Pressenævn, og denne unikke ordning giver anledning til principielle overvejelser. I artiklen konkluderes, at organiseringen som et offentligt organ ikke giver problemer for uafhængigheden. Der peges dog på, at det principielt er uheldigt, at udpegningen af medlemmer til Pressenævnet foretages af justitsministeren.

De vejledende regler om god presseskik er ikke revideret i mange år og giver derfor ikke klar vejledning om hvilke nye problemstillinger, der kan klages over til Pressenævnet. En ajourføring kan være nyttig for borgerne, der overvejer at klage. Det anbefales også, at Pressenævnet strammer kravene til de trykte mediers publicering af nævnets kritik, så de kommer på linje med kravene til tv-stationers publicering af kritik i nyhedsudsendelser. Det anbefales endvidere, at Pressenævnet tager enkelte sager op af egen drift i tilfælde, hvor den krænkede ikke har mulighed for at gøre det. 
Nogle medier har formuleret egne etiske retningslinjer, og enkelte har fulgt op med særlige interne klagesystemer. De har klart bedre mulighed end Pressenævnet for at påvirke det etiske niveau på det enkelte medie, hvis de kombineres med et åbent fagligt miljø. Konklusionen er, at det er værdifuldt for presseetikken, at medierne etablerer egne systemer, men at de ikke kan erstatte Pressenævnets funktion som klageorgan for borgere, der er krænkede og ikke er tilfredse med den behandling, de får hos det enkelte medie.

\section{REFEREN CER}

\section{BØGER}

Frøbert, Knud Aage (2000). Massemediernes frihed og ansvar, Greens Jura, København.

Jørgensen, Oluf (2004). Det handler om ytringsfrihed, forlaget Ajour, Århus.

Kruuse, Helle Nissen (1991). Etik i journalistik. forlaget Ajour, Århus.

Raaum, Odd (2003). Dressur i pressen, Universitetsforlaget, Oslo.

\section{TIDSSKRIFTER}

Ingerslev, Ulla (1998). Pressencevnets virksomhed, Ugeskrift for Retsvæsen B, pp $250 \mathrm{f}$.

\section{BETAENKNINGER OG RAPPORTER}

Forbrugerombudsmanden (2005). Vejledning om skjult reklame, København.

Medieansvarsudvalget (1990). Medieansvar, betænkning 1205/1990, København.

Pressenævnets årsberetninger 1992 - 2004, København.

Udvalg med repræsentanter for DDF, Journalistforbundet og DR (1977). Presseetik, betænkning afgivet marts 1977, København. 